DOI https://doi.org/10.36059/978-966-397-186-5/1-16

\title{
INNOVATIVE TECHNOLOGIES AND PRACTICES OF HUMAN SUBJECTIVATION
}

\section{Polina Herchanivska}

\section{INTRODUCTION}

In the acentric culture of the postmodern, the crisis of identification is increasingly manifesting itself, which consists in the destruction of the conditions of a holistic perception by a subject of himself as an autonomous personality. This process has especially deepened in the context of globalization, when in a single social-cultural field the multi-directional axiological systems have appeared, that greatly complicated the task of human self-identification. I'll draw attention to another aspect: repressions remain an integral element of social-cultural relations in society. Therefore, despite the fact that modern societies have received formal freedoms in the form of human rights, freedom of speech, the possibility of taking part in the political life of society, the threat to the subjectivation of the individual does not disappear. This actualized the study of the problem of human subjectivation in the context of contemporary social-cultural realities.

A number of theoretical and methodological aspects of the problem of human subjectivation in modern society have been developed by such scientists as H. Arendt, T. Adorno, M. Horkheimer, J. Baudrillard, Z. Bauman, J. Galbraith, H. Marcuse, F. Nietzsche, M. Foucault, E. Fromm, M. Hardt, A. Negri and etc. The main paradigms for this phenomenon were formulated, in particular: social-cultural reality creates conditions for the subjectivation; there is a two-way link between the subject and social-cultural reality. Based on these paradigms, we shall determine the specifics of the process of human subjectivation in the conditions of modern Ukrainian society.

Let us first of all comprehend the essence of M. Foucault defined this concept as follows: "I call "subjectivation" the process through which the formation of the subject takes place, more precisely, subjectivity, which, obviously, serves only one of the given possibilities of organizing a certain self-consciousness"1. M. Foucault not only rejects the traditional understanding of subjectivity as an apriori and universal form of human existence, but also develops its new understanding. He states that the

\footnotetext{
${ }^{1}$ Фуко М. (2004) Археология знания. Санкт-Петербург: Гуманитарная Академия.
} 
subjectivation is a process of becoming historically conditioned subjectivity, formed in the process of human development.

In the process of subjectivation, the formation of the individual as a subject takes place. Subjectivation is determined, on the one hand, by external social-cultural processes, when one becomes the object of various programs and of government practices (states, various institutions, social groups, etc). As M. Foucault noted, despite the fact that the state is inherently a totalitarian political force, it is a fairly powerful element of subjectivation ${ }^{2}$.

On the other hand, subjectivation is caused by immanent processes of human self-development, that is, the subject acts as an active beginning of this process. Determinants of internal subjectivity are volitional, intellectual, moral, physical and other efforts of the individual, which help him to harmonize his own internal needs and interests with the social-cultural environment. That is, internal subjectivation is oriented towards reconciling a person's internal world with the external.

So, the subjectivation of the personality is a process and at the same time a condition for the realization of potential human abilities, in the surrounding social-cultural environment.

The process of human subjectivity always occurs in a certain socialcultural context, therefore, we consider this phenomenon from the perspective of such aspects: 1) Ukrainian social-cultural realities in the postmodern era; 2) technologies of mass manipulation and resistance; 3) innovative technologies and practices of human subjectivity.

\section{Ukrainian social-cultural realities in the postmodern}

I note that postmodernism is not so much an era in the development of social reality as of consciousness. First, postmodernism has given new semantics and axeology to atheistic thinking. "The death of God" has become a fundamental metaphor of postmodern philosophy, fixing in its content a paradigmatic attitude towards rejecting the idea of external forced casualness ${ }^{3}$. The introduction of this metaphor into the semantic space of modern culture indicates a reorientation of understanding causality as an external factor in understanding it from the point of view of the immanence of the subject, focusing on the subjectivity of its perception.

Secondly, postmodernism dissociates itself from the metaphysical linear (evolutionist) paradigm of dynamic processes leading to the unification of the ways and forms of historical development: it offers the idea of non-linearity of

\footnotetext{
${ }^{2}$ Ibid.

${ }^{3}$ Грицанов А.А, Можейко М.А. (Ред.) (2001) Постмодернизм. Энциклопедия. Минск: Интерпрессервис: Книжный Дом.
} 
the processes of social-cultural changes. Refusing forced causality, postmodernism interprets transformational processes as self-organizing, and the social-cultural system as an open, self-developing one.

Thirdly, the universal principle of the organization of social-cultural space is plurality, collage. The postmodern model of the historical process determines the coexistence of alternative codes and values in a single socialcultural field. According to Z. Sarder, in this context, the cultural-adaptive potential of the postmodern, aimed at the dialogue of cultures without any restrictions (political-ideological, ethnic, religious) is manifested ${ }^{4}$.

Fourthly, postmodernism breaks with everything connected with metaphysics and, first of all, with logocentrism, which in the context of postmodernity acquires a negative meaning as the reason for forced, repressive, totalitarian social-cultural relations. The reformist position of postmodernism (the refusal to build a universally rational model of the world) excludes the very idea of its integrity, hierarchical structure, harmonious ordering. The fundamental paradigm of the culture of this era is the concept of "chaos", and the basic postulate is "order from chaos". The phenomenon of chaos and instability is interpreted by postmodern reflection as a fundamental basis for the formation of new cultural configurations, and a text devoid of primary content is regarded as an open field for updating plural contents. From the position of S. Lash, chaos permeates all levels of being, and modern social reality is "disorganized capitalism"

Radical changes in the worldview provoked the heterogeneity of the semantic landmarks of the social-cultural thinking of various layers of Ukrainian society: today, in a single social-cultural space, axiological systems co-modern, modern, post-modern coexist. This determined the deepening of the identification crisis: in the complex interweaving of worldview paradigms, it is very difficult for a person to choose a specific life position. Explaining the paradox of modernity, R. Laing expressed the view that personality lacks a sense of individuality, autonomy, self-worth, it experiences its Self as partially alienated from the body ${ }^{6}$.

I note that the crisis of identification occurs against the background of social-cultural entropy in Ukrainian society, which is characterized by postSoviet countries. The situation is characterized by a violation of the integrity of the system of value orientations, forms and norms of social organization and regulation, channels of social-cultural communication, complexes of

${ }^{4}$ Sardar Z. (1998) Postmodernism and The Other: New Imperialism of Western Culture. London: Pluto Press.

${ }^{5}$ Lash S. (1994) Economies of Signs and Space. London: Sage.

${ }^{6}$ Лэнг Р. (1995) Расколотое Я. Санкт-Петербург: Белый Кролик. 
cultural institutions, stratified means of life, ideology, morality, mechanisms of socialization and inculturation of an individual, normative parameters of its social and cultural relevance to the community. This is due to: firstly, the political crisis in the internal development of society, the decline in the efficiency of social regulation institutions; secondly, with the social-economic crisis that has led to major changes in the nature of people's social interests and needs; third, with the crisis of the dominant ideology (secular and religious), which has lost its socially consolidating and mobilizing capabilities. Previous regulators of social life have ceased to dominate the spiritual life of society, and new ones have not yet formed.

The approach to the economic development of Ukrainian society has changed. Instead of the ideological platform on which inter-ethnic interaction took place in the Soviet period, the economic factor becomes decisive. The essence of market relations is also being transformed: private ownership is replaced by public ownership, and the tendency of rapid property stratification is observed.

One of the characteristic features of a society is its extraordinary individualization, and the dominant principle in the human mind is "each for himself".

More and more people are leaving the zone of regulation of consciousness and behavior by means of the dominant in the Ukrainian society cultural system. The efficiency of the process of socialization and inculturation of a person by means of education, the Church, state ideology and propaganda is decreasing. Due to the breaking of stereotypes of consciousness and behavior of people, the devaluation of traditional norms and rules of life, social interaction, morality, value imperatives, and taboo become more evident. People's dissatisfaction with living conditions and orientation to western standards of living become more present. The period of violation of the functional integrity and balance of the social-cultural system is accompanied by a decrease in the level of subjectivation of the person.

Changes in the social-cultural sphere of Ukrainian society are imposed on the matrix of globalization processes. The model of globalization is based on the presumption of multiculturalism as a social phenomenon "the coexistence of many different ethnic, cultural, denominational groups in the same social space" . Its basic mechanism is social-cultural communication, aimed at ensuring active and equal dialogue of different cultures, their mutual understanding and mutual enrichment.

7 Тонкова Е.Г. (2009) Понятие мультикультурализма: основные концепции. Фундаментальные проблемь культурологии (Т. VII, C. 5-16 ). Москва, Санкт-Петербург: Новый хронограф, Эйдос. 
In fact, it's the perfect model. If multiculturalism and the equality of national cultures exist "de jure" and are enshrined in the UNESCO Universal Declaration, then "de facto" they remain only as an intention. According to U. Kimlicka ${ }^{8}$, in Western society, the principle of equality of rights applies only to people who belong to the Christian European culture and share its core values. All other cultural communities (ethnic groups, religious denominations, etc.) tend to experience various forms of political or cultural discrimination. In other words, the principle of equality applies a priori to a limited community, others find themselves marginalized, and a system of regulatory prohibitions is formed for them.

The marginalization of individual groups by social-economic criteria or social-cultural identity has become a flip side to creating a single socialcultural space. Stumbling block in the issue of multiculturalism were, in particular: unequal basic models of national politics (cultural, religious, etc.) of states aimed at developing national identity, consolidation of society; inequality of national legal models.

Thus, in practice, Western democracy has not been able to overcome the misunderstandings associated with ethno-cultural diversity. In response to multiculturalism, the concept of abandoning the idea of integration into the global cultural space arose. Various models of intercultural relations are created, based on the differentiation of national cultures (U. Kimlicka, C. Kukatas) ${ }^{9}$.

Cultural unification in the architectonics of globalization provokes the intensification of the process of human awareness of their belonging to a particular ethnic community. In many countries around the world, people's interest in their roots is reviving, and Ukraine is no exception. Decades of relativization from national values, ideologies and beliefs, the unification of behavior patterns and worldviews offered by the mass media have created a keen sense of loss of identity in Ukrainian society.

However, ethnic identity is a key principle of European democracy in the context of globalization, the main element of which is the creation of a common European social-cultural space while preserving the cultural roots of each ethnic group as the basic unit of the ethnic sphere. Psychological factors intensifying this process are the same for all mankind in the era of radical transformations that cause social instability - is the search for life landmarks. More and more attention is paid to the ways of life of previous generations,

\footnotetext{
${ }^{8}$ Kymlicka W. (2006) Immigration, Multiculturalism and the Welfare State. Ethnics and International Affairs, 20(3), 1-20.

${ }^{9}$ Kukathas Ch. (2003) The Liberal Archipelago: A Theory of Diversity and Freedom. Oxford: Oxford University Press; Kymlicka W. (2006) Immigration, Multiculturalism and the Welfare State. Ethnics and International Affairs, 20(3), 1-20.
} 
people are turning to the faith, traditions, norms and values that were produced by their ancestors.

Aware of being part of a particular ethnic community with its established characteristics, one feels psychologically secure in an unstable, saturated information world. However, through the internationalization of social life, modern ethnic communities are largely detached from ancient traditions, the behavior of ancestors is no longer regarded as a standard. However, humanity is increasingly coming to the conclusion that it is necessary to maintain communication between generations.

While researching the problem at the ethnic level, it should be borne in mind that the culture of the Ukrainian ethnic group has never been homogeneous. At this level one can trace the diversity of forms of intercultural interaction, each of which during social-genesis has developed an immanent system of protective mechanisms for storing and reproducing life experiences and traditions, as well as an immanent sense of identity.

Local (regional) the ethnic cultures do not have a significant gap in typological characteristics: they contain universal traits, common cultural invariants. Therefore, the basis of interregional cooperation, as a rule, is the principle of peaceful coexistence and equal cooperation The interaction between local cultures, which differ in confessional featured and socialcultural development, is more complicated in results and consequences.

Let me give an example of the situation in the western and eastern regions of Ukraine. The prolonged existence of Ukrainian lands in different imperial systems with different cultural and religious orientations, differences in the dynamics of social-economic development of these systems and different direction of the vectors of intercultural contacts contributed to the formation of heterogeneity of regional self-identification. Today, the East of the country is a conglomeration of local cultures with a dominant Orthodox orientation, the West is a congregation of cultures focused on the Western European version of Christianity. As a result, despite the general cultural basis that was formed within the Ukrainian ethnos, there have been repeated cases of rejection of cultural elements of another denomination throughout history, this trend is still being observed today.

Modern integration and differential processes in culture are in dynamic correlation: on the one hand, the development of human civilization is aimed at overcoming intercultural opposition, on the other, on enhancing the potential of each national culture. This is the essence of the contradiction of globalization, which gives rise to a whole set of determinants of reduction of human subjectivity in Ukraine.

Thus, there is a two-way link between social-cultural reality and the subject: social structures create the conditions for subjectivation of the individual, and the individual, in turn, constructs the social-cultural space, influencing the process of social development. 


\section{Technologies of mass manipulation}

Another factor influencing the process of subjectivation is the repressive element of social-cultural regulation of society. Repression in totalitarian societies is usually associated with punishment, but it is manifested not only in punitive measures but also in practices and technologies that carry the threat of suppressing the process of human development, freedom and subjectivity. If terrorism is perceived by the world community as a repressive form of influence, then the techniques of mass manipulation are far from being evaluated by all in a repressive context.

Mass manipulation technologies are social tools of informational and psychological influence on a person (or group of people) by programming certain ideas, tastes, values and needs in him, which prevents him from being subjected. They are an important tool in the hands of actors seeking power and profit. The main purpose of repressive technologies is to exercise control over people and to purposefully transform the social-cultural space through the generation of certain meanings and values. The psyche of the individual is exposed to impact at all levels, both conscious and unconscious.

There are no abstract, unified mass manipulation technologies. The dynamism of social-cultural change requires constant updating of this tool of social practice. Moreover, the threat of subjectivation of man comes from phenomena that almost impossible to exclude from public life (Internet, television, press, advertising, etc.).

$\mathrm{N}$. Chomsky identified ten main ways of manipulating with the help of the media: 1) diverting attention from important problems and shifting the focus to minor aspects; 2) creating a problem and then suggesting a way to solve it ("problem-response-solution"); 3) gradual application method (used in situations where it is necessary for society to take an unpopular measure); 4) delay in execution as a way to "sell" an unpopular decision; 5) appeal to the general public using such arguments, characters, words and intonations as if they were school-age children with developmental delays or mentally disabled individuals; 6) encouraging citizens to be passionate about mediocrity; 7) keeping people in ignorance, cultivating mediocrity; 8) enhancing selfguilt; 9) to know more about people than they know about themselves; 10) emphasis on emotions to a much greater extent than thinking ${ }^{10}$. Of course, this is not a complete list of the media arsenal.

The introduction of mass manipulation technologies into the modern Ukrainian society marks the transition from a direct, undisguised attitude to man, as things are, under conditions of totalitarianism, to influence concealed

${ }^{10}$ Chomsky N. (2011) 10 ways to manipulate using the media. URL: http://inosmi.ru/ world/20110517/169481135.html 
by the slogan of "human rights". While in the totalitarian regime mass manipulation technologies played an important but not dominant role, "their development took place against the background of the continuous radiation of repressive violence in mass forms, which led people to a state of immanent fear" ${ }^{\prime \prime}$, nowadays, these technologies are aimed at on the psychological subordination of man, become a major tool in the social-cultural regulation of society.

However, there is a different point of view on this phenomenon. For example, S. Kara-Murza believes that manipulation is not violence, but a temptation ${ }^{12}$, which must be countered by the resistance potential of man. In its essence, resistance as a structural element of social relations, is a deliberate process of protecting a subject from repressive technologies and practices. It can take different forms of active counteraction (resistance, struggle, dissent, disobedience, confrontation, sabotage, etc.), as well as forms focused on constructing an individual, activating his immanent willpower and striving for freedom.

In this context, attention should be drawn to such point: mass manipulation technologies are firmly entwined in the institutions and practices of modern society, and cannot be immediately abolished in a revolutionary or violent way. Prohibition measures only encourage the search for new, more powerful, repressive algorithms. As experience of world history shows, a much more effective means of resistance in modern conditions is to resort to the inherent intellectual and moral foundations of man, to such determinants of his subjectivity as will and freedom.

According to M. Mozheiko, the will is a "phenomenon of self-regulation by the subject of his behavior and activity, which provides a vector orientation of the immanent states of consciousness on the objectified exterior goal and concentration of efforts to achieve it"13. In concepts, the postmodern concept of "will" is used to refer to a principle that is free and not restricted by the discursive rules of subjectivity.

The starting point of a volitional act is the person's awareness of significance of the formulated purpose, its correspondence (or inconsistency) to the immanent value scales. This act consists of making a decision that is substantially in line with the stated goal and mobilizing efforts for its realization. The result of a volitional act of subject is determined by its immanent attitudes, subjective orientation to certain social values, inclination to a specific set of actions, speed of reaction to the proposed situation, etc.

11 Михайличенко Д.Г. (2011) Субъективация современного человека в контексте технологий массовой манипуляции (Дис. доктора филос. Наук). Уфа.

${ }^{12}$ Кара-Мурза С.Г. (2006) Манипуляциия сознанием. Москва: Эксмо.

${ }^{13}$ Грицанов А.А, Можейко М.А. (Ред.) (2001) Постмодернизм. Энциклопедия. Минск: Интерпрессервис: Книжный Дом. 
Another universals of human subjectivity is freedom, which captures "the possibility of activity and behavior in the absence of external targeting" 14 . However, the absence of external goal setting is not yet a guarantor of true freedom, because it does not exclude the objective-subjective component of activity determined by social-cultural conditions.

Within the framework of social-cultural interpretation, in the content of the concept freedom implicitly incorporates the vector of alternative, conscious opposition to social pressure: freedom is constituted as a result of overcoming non-freedom. The desire for freedom of the modern man is an action aimed at neutralizing the repressive influence of various forms of information and psychological violence. The level of human freedom depends to a large extent on its inherent intellectual and volitional potentials and reactions to information flows. However, this form of resistance must contain a moral dimension, not new, more sophisticated and flexible mass manipulation technologies.

Therefore, successful counteraction to mass manipulation technologies requires rather than regulatory and institutional measures, but the formation of existential conditions for human subjectivation. Forming its own existential space, the person is oriented towards neutralizing the repressive influence of mass manipulation technologies, which requires long efforts aimed at his subjectivation, crystallization of his resistance. Resistance to the repressive influence of mass manipulation technologies is not the goal itself, but a necessary condition for the spiritual development of a modern person and is functionally dependent on its intelligence and social-cultural level of society sophisticated and flexible mass manipulation technologies.

\section{Innovative technologies and practices of human subjectivation}

Today, in an era of identification crisis, when the whole perception of the subject as a personality is destroyed, when a person is unable to clearly define his position in relation to the existing plural axiology, the paradigmatic attitudes of postmodernism are transformed. Deconstructionism is being replaced by a new version of postmodern philosophy (after-postmodernism), the vector of which is shifting markedly towards communication, emphasis is transferred from text reality to communicative reality and centered around the concept of "Other". That is, in contrast to the classical philosophical tradition in which human consciousness has been positioned as object-oriented, as well as postmodernist text-oriented classics, the modern version of postmodernism is actualized through subject-subject relations.

\footnotetext{
${ }^{14}$ Грицанов А.А, Можейко М.А. (Ред.) (2001) Постмодернизм. Энияиклопедия. Минск: Интерпрессервис: Книжный Дом.
} 
In semiotic culturology by Lotman, two basic communication models are identified: through the channels "I"-"I" and "I"-"Other"15. Each act of communication is aimed at solving a specific problem. In auto-communicative structure ("I"-"I"), there is a shift in the code and context of the transmitted message, the content of information is transformed, which leads to a change in the self. Essentially, the auto-communication process is the basis of the cultural identification of a person. At the same time, it acts as a creative cultural mechanism aimed at the formation of new ideas, meanings and artistic forms, as well as a mechanism of socialization and personality development.

If auto-communication realizes itself through the dichotomy "I"-"I", then communication-through dualism "I"-"Other". The communicative culture of personality is a complex system containing creative thinking, the culture of speech impact, the gesture culture and plasticity of movement, culture of perception of communicative actions of the partner, culture of emotions, etc. Communication is a semantic aspect of social inte-raction aimed at achieving social cohesion while maintaining the individuality of each communicator.

It is possible in the presence of the following components: 1) at least two communicators who are endowed with consciousness and use common semiotic means (linguistic, para-linguistic); 2) a situation the sense of which communicators are trying to understand; 3 ) texts reflecting the content of the situation in a common language for them; 4) motives and goals that motivate subjects to communicate; 5) the process of material transmission of text.

Tolerance is the core of postmodern communication. In the process of communication, an informative and existential interaction between the communicants is formed, through which mutual understanding is achieved. As a result of the dialogue the generalization of values takes place, that allows to free the communicative action from inherited patterns of behavior. Mutual understanding is achieved by knowing the language of the Other in all its specificity, complying with dialogue rules devoid of any compulsion (institutional, cultural, etc.) as well as by agreeing action plans. True consensus is achieved through equitable dialogue and clear argumentation.

In the context of verbal-communicative practices of postmodernism, a special place is given to discourse, as "a verbally articulated form of objectification of the content of consciousness, which is governed by the type of rationality dominant in a certain social tradition" ${ }^{\prime 6}$. M. Foucault indicates

15 Лотман Ю.М. (1992) О двух моделях коммуникации в системе культуры. Статьи по семиотике и топологии культуры. (Т. 1, С. 76-90). Таллин: Александра.

${ }^{16}$ Грицанов А.А, Можейко М.А. (Ред.) (2001) Постмодернизм. Энциклопедия. Минск: Интерпрессервис: Книжный Дом. 
that the functioning of discursive practices in the postmodern era is based on immanent rules, concepts, and strategies ${ }^{17}$. If in the framework of the metaphysical tradition, discourse is understood as a rational-logical procedure for deciphering the inherent content of the world, then postmodernism interprets discursive practices as an act of communication. Its space contains linguistic practices and behaviors that are manifested in accessible, forms that are necessary to understand the text. They give an idea of the communication participants, their goals, as well as the conditions of formation and perception of the message.

Discourse is an essential component of sociocultural engagement with a particular social-cultural and social-psychological context. It occurs in a content field with inherent paradigm and particular linguistic environment. Its communicative acts manifest specific vocabulary, semantics, pragmatics, syntax, characteristic of a specific social-cultural sphere. Therefore, the term "discourse" needs to be properly defined ("political discourse", "scientific discourse", "hilosophical discourse", "journalistic discourse", etc.).

The main axiological paradigms of modern discourse are dialogism, pluralization of points of view. Postmodernism fundamentally denies the onedimensionality and stability of truth, its universalist understanding. Discourse creates (often spontaneously) conditions for its multi-vector structuring. In the postmodern interpretation there is a departure from the understanding of its content as a final statement, which does not imply any variation. Attention is focused on nonsense as a determinant of content openness. This approach is linked to the general postmodern paradigm regarding the chaos of the universe.

By focusing on the spontaneity of discourse, postmodernism brings to the fore a creative factor, which opens up opportunities for unpredictable decisions. Thus, the linguistic turn, made by the philosophy of the XX century, marked the change of paradigm (the transition from the philosophy of consciousness to the philosophy of language).

This process develops in parallel with the deepening of the essential characteristics of the consumption society and the expansion of the information and communication space, which is a common structured media system. According to J. Baudrillard, the development of communication, and especially of mass communication, forms such a phenomenon as "mass"18, an integral feature of which is anonymity and incorporeity. The

\footnotetext{
${ }^{17}$ Фуко М. (2004) Археология знания. Санкт-Петербург: Гуманитарная Академия.

18 Бодрийар Ж. (2000) В тени молчаливого большинства, или конеи социального = A l'ombre des majorités silencieuses, ou la fin du social. Екатеринбург: Изд-во уральского университета.
} 
mass is not a carrier of autonomous consciousness, it is a multiple subject living in the information technology world, an active consumer of what the media offers.

By limiting the perception of the surrounding space by the sphere of signs, the mass loses touch with everyday reality, replacing it with virtual reality. Communication for her is a continuous absorption of signs. It translates all messages from rational plan into plan imaginary and forces it to circulate according to its immanent rules. Communicative manipulation often transforms the passive mass into an object of information aggression, forcing it into a new vision of the social world. In modern conditions, a new type of mass culture is being formed, and its conceptual field is gaining new content. It reflected the features of the postmodern era - carnivalization, hybridity, language play, etc. The main paradigms of mass culture are: focus on the use of manipulative techniques and technologies for managing cultural objects, states and processes; focus on solving urgent immediate problems. This is especially evident in advertising and political technologies.

The mass culture space of the postmodern era is very mosaic and, due to the dynamism of information technology, is extremely mobile. Manipulative technologies, deforming the content of modern mass culture, lead to the active transformation of its axiological and semiotic spheres. Important social values such as "justice", "freedom" are transformed, vital values come on the first plan. In the semiotic space, signs and symbols become objects of conscious production, creating virtual communicative reality. The main task of mass culture is to refocus consumer attention from the problematic interpretation of real life to the spectacular perception of entertainment products, to emotional relaxation and the game of human imagination. The holistic metaphysical system of knowledge and values has been changed by a system of changing attitudes that are broadcast through mass communication channels.

In the context of globalization and virtualization of modern society, mass culture becomes an important resource for constructing identity in society, giving individuals a certain set of cultural patterns, codes, and styles. Thanks to innovative technologies, the system of social-cultural design, programming and modeling, it becomes one of the main institutionalization mechanisms influencing the process of social development, defining its value orientations. Despite its focus on the "average" consumer level, mass culture is certainly a manifestation of a new type of culture that accumulates social experience of human life at the post-industrial stage of social evolution, assuming the functions of personality inculturation in the context of Ukrainian realities.

Postmodern philosophy in a new way articulates an understanding of linguistic reality. The modern stage of its development was the concept of 
language games K.-O. Apeal ${ }^{19}$. I note that the term "language games", introduced in the scientific" circulation by L. Wittgenstein, means one whole - the language and the actions with which it is interwoven ${ }^{20}$. If earlier the interpretation of this concept in the context of cultural practices was based on the interaction between the subject and the text, then K.-O. Appeal gives it new content by considering it as subject-subject communication. In this context, language becomes not only a mechanism of objectification of information, but also a mediator of understanding between subjects. The regulatory mechanism of communication (interpersonal, public or mass), by K.-O. Apel, becomes a dialogical understanding of the subjects.

The paradigmatic basis of language games is to understand them as a form of life. The gaming industry needs a specific field that simulates gaming reality, and the gaming community creates virtual reality for itself. Hi ceases to live in the objective world, and language games become a means of experiencing this conditional reality.

In J. Huizinga's interpretation ${ }^{21}$, play is an area of emotionally rich communication that unites people with different social status and professional experience. It transfers the accent from the usual communicative norms and traditions to linguistic relaxation, permissiveness. The highest value of the game is not the result, but the gameplay itself. The game frees consciousness from the oppression of stereotypes, gives the individual the possibility of selfrealization that goes beyond his social roles, promotes his self-expression. The game has two original elements: the first is related to the emotional experiences of players and recipients; the second, on the contrary, is rational in nature, within which the rules of the game are clearly followed.

The language game has thematic and situational demarcation. Giving maximum freedom to its participants, it is realized within the context of which is reduced to certain rigid rules, determined by a specific situation. Therefore, a language game is creativity by certain rules, a process of searching and finding the truth, the result of which cannot be determined in advance. Its rules are not fixed forever; they can vary throughout the game. When involved in the game, the communicator introduces an element of improvisation into the text, which often results in a result other than the programmed one.

Pluralism, the dynamism of social being determine the emergence of various language practices with different rules and specific language. An essential component of postmodern culture are performance and happenings,

\footnotetext{
${ }^{19}$ Апель К.-О. (2001) Трансформация философии. Москва: Логос.

${ }^{20}$ Витгенштейн Л. (1995) Философские исследования (Ч. 1). Москва: Гнозис.

${ }^{21}$ Хейзинга Й. (1997) Homo Ludens. Cтатьи по истории культуры. Москва: ПрогрессТрадиция.
} 
in which the role of complicity and co-creation of the artist and the recipient increases, and the distance between them decreases. Non-pragmatism ("action for the sake of action"), dialogue, development in time, a combination of different types of art, primacy of action and gesture, provocation, social orientation of actions characterize performance and happenings.

These forms are syncretic forms of art. In them, painting, graphics, sculpture, theater, music, mime art create an unbreakable unity. However, unlike theatrical action, this actions are not rehearsed, they have not clear plot. Performance and happenings reflect the problem of the modern postmodern. The authors actively address social and political topics, and criticize the authorities. Their main feature is the effect of feedback between creator and viewer. In both cases, the recipient becomes an observer and accomplice of creative action, in which improvisation and chance play a big role.

However, there are some differences between these forms. Performance, while refraining from excessive theatricality, still remains a form of parateatral action. The play is transferred from the theater to museums and galleries and is performed according to a certain plan (scenario). Hapening is also a theatrical act, but the play have not a clear script. The role of improvisation, spontaneity, unpredictability in it is more important than performance, higher the degree of activity of the audience. It is based on the spontaneous reactions of the performers, which provoke the play activity of the audience. Today a new form of actionism has emerged, Internet Street Performance. Promotional videos and photos, falling into the Internet space, significantly increase the number of viewers.

The game nature is also evident in the flashmob, which is interpreted as a form of entertainment and experimentation with virtual and real realities. This is a pre-planned mass action organized through the Internet or other modern communication means to draw public attention to certain problems. The purpose of these actions is different: entertainment, trying to get thrills, disruption of daily life and more. Flashmobs can acquire political (politicalmob) or social (social-mob) shades, often focused on group protest (flash protests), but are always organized according to certain rules: anonymity of participants of the action; strict adherence to the rules of the game and its scenario; violation of laws and moral principles of society; prompt holding of the action; flashback action with a surprise effect. Flashmob fully implements the game principle, the motive of which is not the result, but in the process. It is in games that society monifestes his understanding of life and the world.

Thus, the plurality, the dynamism of the postmodern, its focus on constructing its own reality gave impetus to the development of various contemporary cultural practices (discourses, language games, etc.) with different rules and specific language. 


\section{CONCLUSIONS}

As a result of the analysis of the problem of subjectivation of the modern man we come to the following conclusions: 1) subjectivation is the process of becoming historically conditioned subjectivity of man; there is a two-way link between social-cultural reality and the subject: social structures form the conditions for subjectivation of the individual, and the individual, in turn, constructs the social-cultural space; 2) an important factor influencing the process of subjectivation is the repressive element of social-cultural regulation of society; the most effective tool of repression in modern conditions is the technology of mass manipulation; 3) effective protection against informationpsychological influence on a person is to appeal to immanent intellectual and moral foundations of man, to such determinants of his subjectivation as will and freedom; resistance to the repressive influence of mass manipulation technologies is not the goal itself, but a necessary condition for human subjectivation; 4) vector of the process of human subjectivation shifted towards communication at the present stage of the post-modern (afterpostmodern); the main axiological paradigms of modern discourse are dialogism, reinforcement of one's personality, pluralisation of points of view.

\section{SUMMARY}

The section of the monograph is devoted to one of the fundamental problems of modern cultural studies. The process of human subjectivation in modern Ukrainian society is analyzed. The influence of social-cultural realities on the process of subjectivation is studied. The modern technologies of mass manipulation are investigated as repressive forms of informationpsychological impact on a person. It is shown that an effective way to resist the information-psychological impact on a person is to appeal to his immanent intellectual and moral foundations. Innovative technologies and practices of human subjectivation is studied. It is shown that in modern conditions, the vector of human subjectivation is oriented towards communication. The main axiological paradigms of modern discourse are dialogism and pluralization of points of view.

\section{REFERENCES}

1. Apel K.-O. (2001) The transformation of philosophy. Moscow: Logos (in Russian).

2. Baudrillard J. (2000) In the shadow of the silent majority, or the end of social =A l'ombre des majorités silencieuses, ou la fin du social. Yekaterinburg: Publishing House of the Ural University (in Russian).

3. Wittgenstein L. (1995) Philosophical studies (Vol. 1). Moscow: Gnosis (in Russian). 
4. Kara-Murza S.G. (2006) Manipulation of consciousness. Moscow: Publisher Eksmo (in Russian).

5. Lotman Yu. (1992) About two models of communication in the culture system (Vol. I). Tallinn: Alexandra (in Russian).

6. Laing R.D. (1995) The Shattered "I". St. Petersburg: White Rabbit (in Russian).

7. Mikhaylichenko D.G. (2011) Subjectivization of modern man in the context of technologies of mass manipulation Chelyabinsk ( $\mathrm{PhD}$ Thesis) (in Russian).

8. Gritsanov A.A., Mozheiko M.A. (Eds.) (2001) Postmodernism. Encyclopedia. Minsk: Interpress service; Book House (in Russian).

9. Tonkova E.G. (2009) The concept of multiculturalism: basic concepts. Fundamental problems of culturology (T. VII, S. 5-16). Moscow, St. Petersburg: New Chronograph, Eidos (in Russian).

10. Foucault M. (2004) Archeology of knowledge. St. Petersburg: Humanitarian Academy (in Russian).

11. Huizinga J. (1997) Homo Ludens. Articles on the history of culture. Moscow: Progress -Tradition (in Russian).

12. Chomsky N. (2011) 10 ways to manipulate using the media. Retrieved from: http://inosmi.ru/world/20110517/169481135.html (in Russian).

13.13 Kukathas Ch. (2003) The Liberal Archipelago: A Theory of Diversity and Freedom. Oxford: Oxford University Press (in English).

14. Kymlicka W. (2006) Immigration, Multiculturalism and the Welfare State. Ethnics and International Affairs, 20 (3), 1-20.

15. Lash S. (1994) Economies of Signs and Space. London: Sage (in English).

16. Sardar Z. (1998) Postmodernism and The Other: New Imperialism of Western Culture. London: Pluto Press (in English).

\section{Information about the author:}

Polina Herchanivska,

Doctor of Cultural Studies, Professor, Head of the Department of Cultural Studies and information communications, The National Academy of Culture and Arts management 01015, Lavrska str., 9, Bldg. 15, Kyiv, Ukraine

ORCID ID: orcid.org/0000-0003-3647-6265 